Article

\title{
Microbial Monitoring as a Tool for Preventing Infectious Risk in the Operating Room: Results of 10 Years of Activity
}

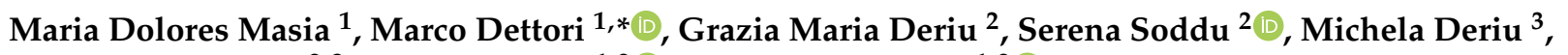 \\ Antonella Arghittu 2,3, Antonio Azara 1,2 (D) and Paolo Castiglia 1,2 (D) \\ 1 Department of Medical, Surgical and Experimental Sciences, University of Sassari, 07100 Sassari, Italy; \\ mdmasia@uniss.it (M.D.M.); azara@uniss.it (A.A.); castigli@uniss.it (P.C.) \\ 2 University Hospital in Sassari, 07100 Sassari, Italy; mariagrazia.deriu@aousassari.it (G.M.D.); \\ sere2111@gmail.com (S.S.); arghittu.antonella@gmail.com (A.A.) \\ 3 Department of Biomedical Sciences, University of Sassari, 07100 Sassari, Italy; micheladeriu94@gmail.com \\ * Correspondence: madettori@uniss.it; Tel.: +39-079-228-467
}

Citation: Masia, M.D.; Dettori, M.; Deriu, G.M.; Soddu, S.; Deriu, M.; Arghittu, A.; Azara, A.; Castiglia, P. Microbial Monitoring as a Tool for Preventing Infectious Risk in the Operating Room: Results of 10 Years of Activity. Atmosphere 2021, 12, 19. https://dx.doi.org/10.3390/atmos 12010019

Received: 18 November 2020 Accepted: 22 December 2020 Published: 25 December 2020

Publisher's Note: MDPI stays neutral with regard to jurisdictional claims in published maps and institutional affiliations.

Copyright: () 2020 by the authors. Licensee MDPI, Basel, Switzerland. This article is an open access article distributed under the terms and conditions of the Creative Commons Attribution (CC BY) license (https: / / creativecommons.org/ licenses/by/4.0/).

\begin{abstract}
Environmental microbial contamination in the operating room (OR) can favour contamination of the surgical wound, posing the risk of infection of the surgical site. Thus, environmental monitoring is a useful tool for assessing environmental health and the effectiveness and efficiency of the measures adopted to control the risk of infection in the OR. This work aimed to analyse the long term environmental quality of 18 ORs throughout Sardinia, Italy, through the quantitative and qualitative characterisation of the microbial flora present in the air and on surfaces, in order to evaluate the trend over time, including in relation to any control measures adopted. The results of the sampling carried out in the period from January 2010 to December 2019 have been extrapolated from the archive-database of the Laboratory of the Hygiene and Control of Hospital Infections Unit of the University Hospital in Sassari. During the period in question, 188 air evaluations were carried out, both in empty rooms and during surgery, and 872 surface samples were taken. When the air was monitored, it emerged that significant contamination was detectable in a reduced number of examinations and a limited number of rooms. Microbial load values higher than the reference values may have been mainly determined by sub-optimal operation/maintenance of the air conditioning system. Surface testing showed a good level of sanitisation, given the low percentage of non-compliant values detected. The possibility of having data available on environmental quality is a useful educational and training tool both for those responsible for sanitisation procedures and the surgical team, in order to increase awareness of the effects of a lack of compliance with behavioural standards.
\end{abstract}

Keywords: indoor air quality; air monitoring; surfaces monitoring; surgical site infection; operating room; healthcare-associated infections

\section{Introduction}

The operating room (OR) is one of the areas of the hospital most at risk of infections. In Europe and the United States, surgical site infections (SSIs) are the second most frequent cause of healthcare-associated infections (HAIs) and are the most common type of HAIs in low and middle-income countries [1]. The incidence varies according to the surgical class and its risk index [2]. In Europe, it varies between $0.5 \%$ and $10.1 \%$, depending on the type of surgical intervention [3]; in Italy, the National Surveillance System of Surgical Site Infections reported an incidence of $2.6 \%$ (range from $0.4 \%$ to $8.9 \%$ depending on the type of surgery) [4]. Overall, SSIs are linked to one-third of post-operative deaths and represent $8 \%$ of all deaths caused by HAIs [5]. The available data indicate a significant economic impact, determined by the increase in the duration of hospitalisation, readmission to hospital, additional surgical procedures, and/or admission to intensive care units [3,6]. In Europe, the cost attributable to SSIs is likely to be underestimated at between 1.5 and 19 billion Euros per year [1,7]. 
Among the various factors that can determine the onset of SSIs, the level of environmental microbial contamination in the OR must be taken into consideration [8-11]. In particular, several studies show that, in the OR, microbial contamination of the air may favour contamination of the surgical wound, thus posing the risk of infection of the surgical site [10,12-14]. In fact, airborne microorganisms can settle directly on the wound or be transferred to it from contaminated surfaces [15]. In this context, the assessment and control of airborne and sedimented microbial flora in the OR are useful tools for assessing environmental health and the effectiveness and efficiency of the measures taken to achieve and maintain it. The detection of microbial contamination through environmental monitoring may reflect shortcomings or failures of structural, organisational, and behavioural aspects. Indeed, the adequacy of these aspects is fundamental to controlling the risk of infections in the OR [16].

The aim of this work is to analyse the long term environmental quality of ORs, through the quantitative and qualitative characterisation of the microbial flora present in the air and on surfaces, in order to evaluate its trend over time, including in relation to any control measures adopted over the years.

\section{Methods}

\subsection{Setting}

The study, covering the period from January 2010 to December 2019, involved testing in 18 ORs in northern Sardinia, with a catchment area of 600,000 inhabitants and an average annual volume of activity quantifiable in approximately 8400 surgical DRG (diagnosis related groups). The rooms, concerning various specialties, are all equipped with turbulent flow ventilation and air conditioning systems. For each room examined, air and surface sampling was performed according to the methods reported below. If values higher than the standard were detected in at least one sample, the outcome of the examination was considered positive.

\subsection{Microbiological Testing of the Air}

In order to characterise the microbial flora, air samples were taken with International pbi Surface Air System (VWR International, Milan, Italy) containing Plate Count Agar plates for the qualitative/quantitative determination of the bacterial flora and Sabouraud dextrose agar plates for determining fungi. In accordance with the Guidelines on Occupational Safety and Hygiene Standards in the Operating Room outlined by ISPESL (Istituto Superiore per la Prevenzione e la Sicurezza del Lavoro), each examination consisted of samples taken under two separate conditions: with the OR empty ('at rest'), in order to evaluate the effectiveness of sanitisation procedures and the functioning of the heating, ventilation and air-conditioning (HVAC) systems; and during surgery ('operational'), in order to evaluate both the HVAC systems and the operators' compliance with behavioural procedures [16].

For each of these conditions (at rest, operational), air was taken from two different zones: at the operating table ('bed') and at the air inlet vents of the air conditioning system ('air inlet'). Finally, for each sampling zone, 2 successive samples of $200 \mathrm{~L}$ of air each were collected. The results were expressed as an average value of colony-forming units per cubic metre of air $\left(\mathrm{CFU} / \mathrm{m}^{3}\right)$ (Figure 1).

As suggested by ISPESL, for interpreting the results of the bed area, the British reference limits have been used. These guidelines recommend, for the type of ORs considered, the maximum limit of $35 \mathrm{CFU} / \mathrm{m}^{3}$ at rest and $180 \mathrm{CFU} / \mathrm{m}^{3}$ in operational [16,17]; for the air inlets, the maximum value of $35 \mathrm{CFU} / \mathrm{m}^{3}$ has also been used, a value we have identified, following experience in the field, as indicative of the correct functioning and maintenance of the air conditioning system [18]. For the evaluation of contamination by fungi, given the lack of specific national and international reference standards, its presence/absence has been taken into account. Where present, the total fungal organisms load 
value $\leq 15 \mathrm{CFU} / \mathrm{m}^{3}$ has been considered "acceptable", as recommended in the literature for environments equipped with air handling units with high-efficiency filters [19,20].

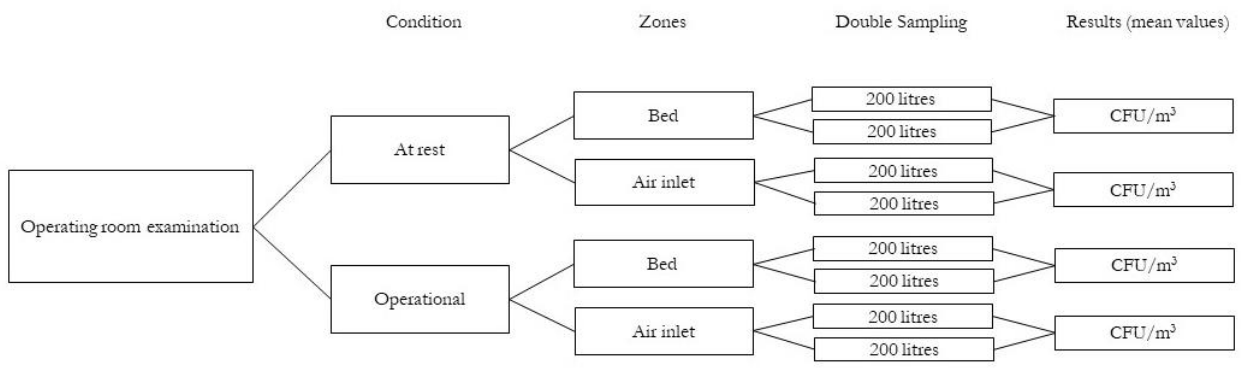

Figure 1. Flow chart of operating room air examination method.

\subsection{Microbiological Testing of Surfaces}

Testing was carried out on the most critical surfaces: the operating table, the anaesthesia trolley, the instrument table, the scialytic lamp, the floor, and the walls. Sampling was carried out using $24 \mathrm{~cm}^{2}$ RODAC (Replicate Organism Direct Agar Contact) plates containing Plate Count Agar and Sabouraud dextrose agar, with a neutraliser added to inhibit the residual activity of the disinfectant used on the surfaces during sanitisation. Surface sampling was carried out under at rest conditions. The results have been interpreted according to the ISPESL Guidelines which provide for values of $\leq 5 \mathrm{CFU} /$ plate for ORs and deem acceptable values between $>5$ and $\leq 15 \mathrm{CFU} /$ plate in the absence of Staphylococcus aureus, Enterobacteria, Pseudomonas spp., and Aspergillus spp. [16].

\subsection{Statistical Analysis}

Data were entered on Excel (Microsoft Office, Microsoft Corporation, Redmond, WA, USA) and analysed. Qualitative variables were summarised as absolute and relative (percentages) frequencies, whereas quantitative variables were summarised with the measures of position and variability of values, depending on their parametric distribution.

\section{Results}

\subsection{Microbiological Monitoring of the Air}

In the period 2010-2019, a total of 188 examinations were carried out. Of which, for organisational reasons, $158(84 \%)$ were carried out both in empty rooms and during surgery, $28(14.9 \%)$ only in at rest conditions, and $2(1.1 \%)$ only when operational. In both conditions, the number of samplings carried out at the air inlet level was slightly lower $(3.8 \%$ at rest, $1.9 \%$ operational) than those carried out in the bed area, as the ventilation system was not in operation at the time of sampling. Depending on technical and organisational reasons (the room's specialty, interventions of maintenance, renovation of the air conditioning system, etc.) the number of examinations per room varied from a minimum of 7 to a maximum of 14 (Table 1).

At rest, the median value of bacterial load was $38.2 \mathrm{CFU} / \mathrm{m}^{3}$ (range 0-320; IQR: 13.1-68.9) near the bed and $20 \mathrm{CFU} / \mathrm{m}^{3}$ (range $0-330 \mathrm{CFU} / \mathrm{m}^{3}$; IQR: $5-50$ ) at air inlet level; during the operating activity, the median values recorded in the bed and air inlet zones were $66.8 \mathrm{CFU} / \mathrm{m}^{3}$ (range $6.7->1000 \mathrm{CFU} / \mathrm{m}^{3}$; IQR: $36.5-122.2$ ) and $47.5 \mathrm{CFU} / \mathrm{m}^{3}$ (range $0-712.5 \mathrm{CFU} / \mathrm{m}^{3}$; IQR: $16.7-102.5$ ) respectively. Overall, $70.7 \%$ of the examinations carried out showed bacterial load values that did not comply with the standards (positive examinations); of which $29.3 \%$ only at rest conditions, $22.6 \%$ only when operational and $48.1 \%$ in both conditions. In particular, $55.4 \%$ of at rest evaluations showed values higher than the standards indicated, with $51.0 \%$ (bed) and $32.8 \%$ (air inlet) of the values detected not conforming. When operational, non-compliant bacterial load values were found in $58.8 \%$ of the evaluations, with non-compliant values in $13.1 \%$ and $56.9 \%$ at bed and air inlet level, respectively. 
Table 1. Air: distribution of examinations per year and condition.

\begin{tabular}{|c|c|c|c|c|c|c|c|}
\hline Year & $\begin{array}{l}\text { No. ORs } \\
\text { Monitored }\end{array}$ & Examinations & $\begin{array}{c}\text { At Rest } \\
\text { Evaluations }\end{array}$ & $\begin{array}{l}\text { Operational } \\
\text { Evaluations }\end{array}$ & $\mathrm{AR}+\mathrm{OP}$ & AR Only & OP Only \\
\hline 2010 & 15 & 22 & 22 & 19 & 19 & 3 & 0 \\
\hline 2011 & 16 & 21 & 21 & 17 & 17 & 4 & 0 \\
\hline 2012 & 18 & 18 & 18 & 16 & 16 & 2 & 0 \\
\hline 2013 & 18 & 27 & 27 & 21 & 21 & 6 & 0 \\
\hline 2014 & 18 & 19 & 19 & 14 & 14 & 5 & 0 \\
\hline 2015 & 18 & 19 & 18 & 16 & 15 & 3 & 1 \\
\hline 2016 & 18 & 21 & 21 & 19 & 19 & 2 & 0 \\
\hline 2017 & 14 & 15 & 14 & 13 & 12 & 2 & 1 \\
\hline 2018 & 14 & 14 & 14 & 14 & 14 & 0 & 0 \\
\hline 2019 & 12 & 12 & 12 & 11 & 11 & 1 & 0 \\
\hline Total & & 188 & 186 & 160 & 158 & 28 & 2 \\
\hline
\end{tabular}

LEGEND: $\mathrm{AR}=$ at rest; $\mathrm{OP}=$ operational; ORs = operating rooms.

Statistics (minimum, maximum, mean, standard deviation, median, interquartile range) of the positive evaluations are reported in Table 2.

Table 2. Air: quantitative analysis of positive examinations: measures of position and variability of values $\mathrm{CFU} / \mathrm{m}^{3}$.

\begin{tabular}{cccccc}
\hline \multirow{2}{*}{ Statistics } & \multicolumn{2}{c}{ At Rest } & \multicolumn{2}{c}{ Operational } \\
\cline { 2 - 6 } & Bed & Air Inlet & Bed & Air Inlet & 37 \\
\hline Minimum & 37 & 36.1 & 180.8 & 712.5 \\
\hline Maximum & 320 & 330 & $>1000$ & $101.6(79.7)$ \\
\hline Mean (Standard Deviation) & $81.9(50.3)$ & $79.1(51.3)$ & $274.2(174.8)$ & $95(53.9-122.5)$ \\
\hline Median (Interquartile Range) & $67.5(52.5-88.8)$ & $67.5(50-85)$ & $231.5(196.3-270.4)$ & \\
\hline
\end{tabular}

Taking the data for each year separately, there is an almost constant percentage reduction over the years of positive examinations, ranging from $100 \%$ of examinations carried out in 2010 to $41.7 \%$ of those carried out in 2019, with the lowest percentage recorded in 2018 (35.7\%) (Figure 2).

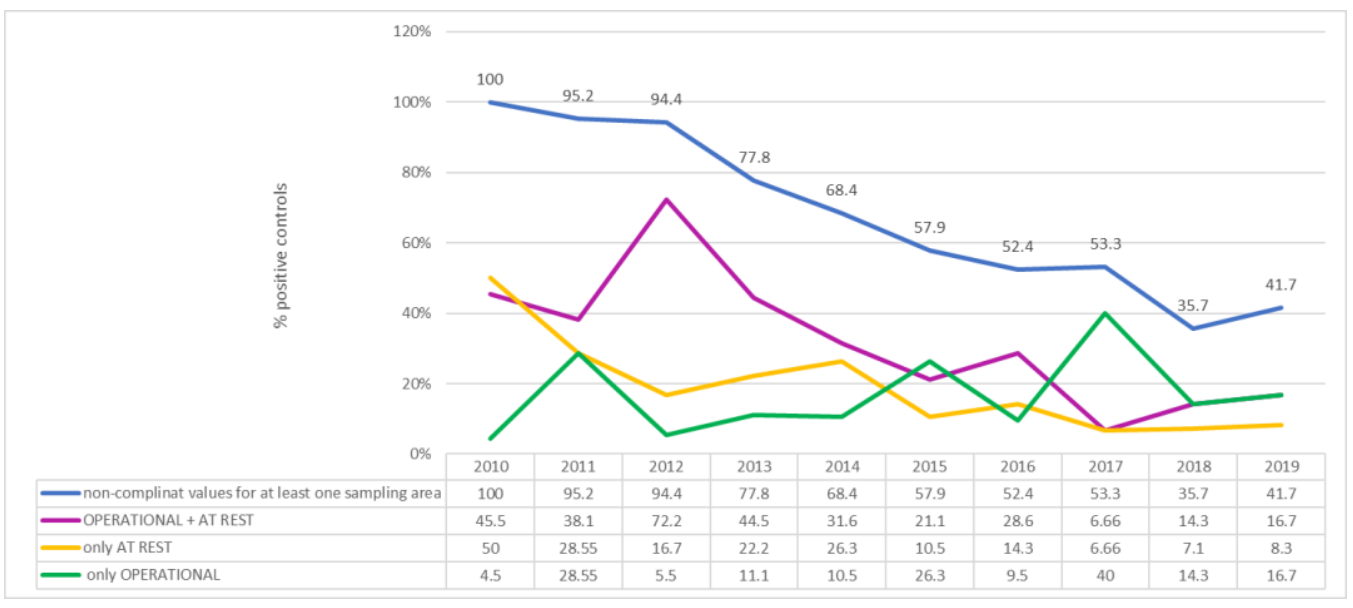

Figure 2. Air: qualitative analysis, percentage of positive examinations per year. 
Over the 10 years under consideration, all of the rooms have shown at least one positive examination. The percentage of positive examinations observed in each room varies from a minimum of $14.3 \%$, observed in only one room, to $100 \%$ observed in two of the rooms.

From a qualitative point of view, in addition to the common microbial flora in the environment, Pseudomonadaceae was isolated in $47.9 \%$ of the examinations (of which Pseudomonas aeruginosa in $7.8 \%$ ), Enterobacteriaceae in $28.7 \%$, Staphylococcus aureus in $27.7 \%$, of which $13.5 \%$ were methicillin-resistant (methicillin-resistant Staphylococcus aureus, MRSA) and coagulase-negative methicillin-resistant staphylococci in $21.8 \%$. The presence of fungimoulds and/or yeasts - was detected in $81.9 \%$ of examinations, $35 \%$ of which were above the value indicated in the literature $\left(\leq 15 \mathrm{CFU} / \mathrm{m}^{3}\right)$. Figure 3 shows the qualitative aspect of fungal contamination.

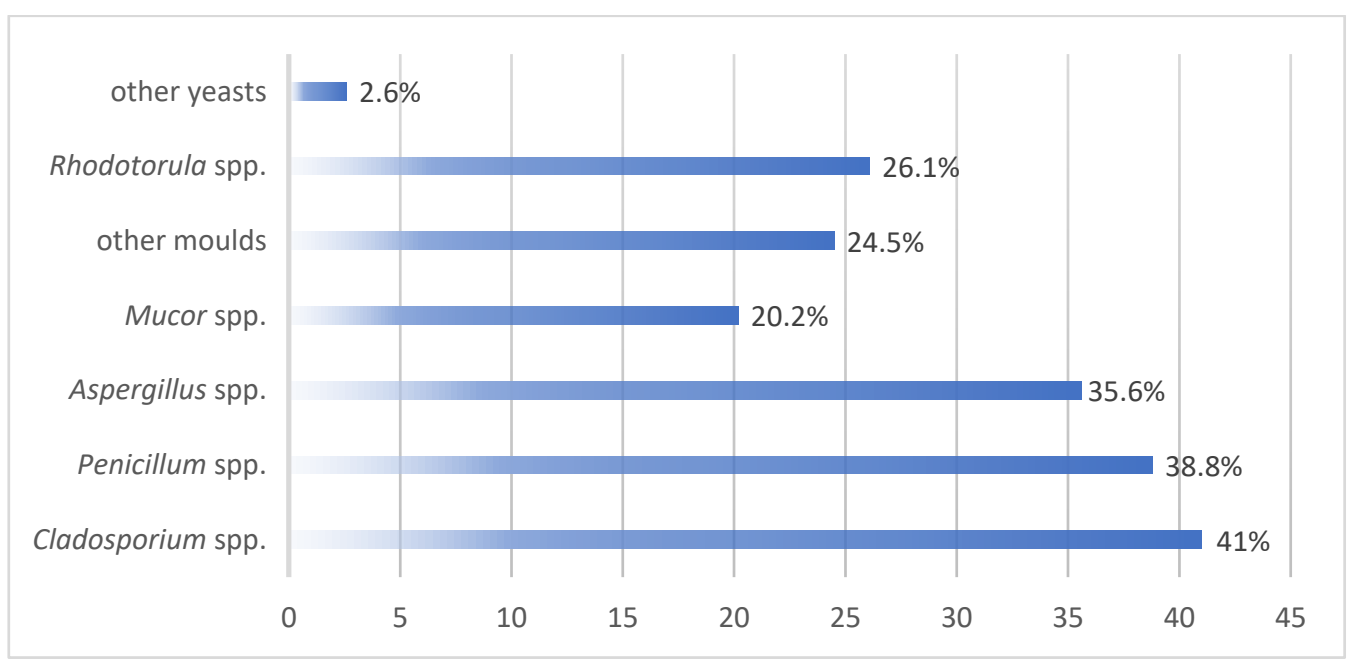

Figure 3. Qualitative aspects of fungal contaminations.

The highest percentage of positive examinations for fungi was observed in 2011 and 2012 (95.2\% and $94.4 \%$ of examinations).

\subsection{Microbiological Monitoring of Surfaces}

Microbiological monitoring of surfaces has been carried out since 2011, and has been performed on surfaces in 17 rooms. A total of 870 samples were taken, almost equally distributed among the different types of surfaces considered. Seventy per cent of the samples showed the presence of microbial flora with a density between 1 and $>50 \mathrm{CFU} /$ plate (median value $4 \mathrm{CFU} /$ plate; IQR: 2-9). Considering the reference values indicated by ISPESL, in $84.7 \%$ of the contaminated surfaces the microbial density was within the standard limits for surfaces in critical environments; in particular, $62.1 \%$ of the sampling was $\leq 5 \mathrm{CFU} /$ plate, and $22.6 \%$ was between 6 and $15 \mathrm{CFU} /$ plate. By contrast, in $15.1 \%$ the microbial density was higher than $15 \mathrm{CFU} /$ plate and in 1 case it was not assessable due to the presence of a patina (Table 3).

The most critical surfaces were the floors, for which $36.0 \%(45 / 125)$ of the samples showed microbial load above the recommended levels, followed by the scialytic lamps with $16.0 \%(20 / 125)$ of the non-compliant samples (Figure 4). 
Table 3. Surfaces: quantitative analysis.

\begin{tabular}{|c|c|c|c|c|c|c|c|c|}
\hline & Bed & $\begin{array}{c}\text { Anaesthesia } \\
\text { Trolley }\end{array}$ & $\begin{array}{l}\text { Scialytic } \\
\text { Lamp }\end{array}$ & $\begin{array}{c}\text { Instrument } \\
\text { Table }\end{array}$ & Floor & Wall & $\begin{array}{l}\text { Anaesthesia } \\
\text { Machine }\end{array}$ & Total \\
\hline Flora absent & $\begin{array}{c}41.3 \% \\
(52 / 126)\end{array}$ & $\begin{array}{c}27.6 \% \\
(34 / 123)\end{array}$ & $\begin{array}{c}16 \% \\
(20 / 125)\end{array}$ & $\begin{array}{c}38.4 \% \\
(48 / 125)\end{array}$ & $4 \%(5 / 125)$ & $\begin{array}{c}50.4 \% \\
(63 / 125) \\
\end{array}$ & $\begin{array}{c}32.2 \% \\
(39 / 121)\end{array}$ & $\begin{array}{c}30 \% \\
(261 / 870) \\
\end{array}$ \\
\hline Flora present & $\begin{array}{c}58.7 \% \\
(74 / 126)\end{array}$ & $\begin{array}{c}72.4 \% \\
(89 / 123)\end{array}$ & $\begin{array}{c}84 \% \\
(105 / 125)\end{array}$ & $\begin{array}{c}61.6 \% \\
(77 / 125)\end{array}$ & $\begin{array}{c}96 \% \\
(120 / 125)\end{array}$ & $\begin{array}{c}49.6 \% \\
(62 / 125)\end{array}$ & $\begin{array}{c}67.8 \% \\
(82 / 121)\end{array}$ & $\begin{array}{c}70 \% \\
(609 / 870)\end{array}$ \\
\hline $\begin{array}{c}\leq 5 \\
\mathrm{CFU} / \text { plate }\end{array}$ & $\begin{array}{c}77 \% \\
(57 / 74)\end{array}$ & $\begin{array}{c}69.6 \% \\
(62 / 89)\end{array}$ & $\begin{array}{c}57.2 \% \\
(60 / 105)\end{array}$ & $\begin{array}{c}71.4 \% \\
(55 / 77)\end{array}$ & $\begin{array}{c}30.8 \% \\
(37 / 120)\end{array}$ & $\begin{array}{c}80.6 \% \\
(50 / 62)\end{array}$ & $\begin{array}{c}69.5 \% \\
(57 / 82)\end{array}$ & $\begin{array}{c}62.1 \% \\
(378 / 609)\end{array}$ \\
\hline $\begin{array}{l}>5 \text { and } \leq 15 \\
\text { CFU/plate }\end{array}$ & $\begin{array}{c}16.2 \% \\
(12 / 74) \\
\end{array}$ & $\begin{array}{c}22.5 \% \\
(20 / 89) \\
\end{array}$ & $\begin{array}{c}23.8 \% \\
(25 / 105) \\
\end{array}$ & $\begin{array}{c}22.1 \% \\
(17 / 77) \\
\end{array}$ & $\begin{array}{c}31.7 \% \\
(38 / 120) \\
\end{array}$ & $\begin{array}{l}12.9 \% \\
(8 / 62) \\
\end{array}$ & $\begin{array}{c}22 \% \\
(18 / 82) \\
\end{array}$ & $\begin{array}{c}22.6 \% \\
(138 / 609) \\
\end{array}$ \\
\hline $\begin{array}{c}>15 \\
\text { CFU/plate }\end{array}$ & $6.8 \%(5 / 74)$ & $7.9 \%(7 / 89)$ & $\begin{array}{c}19 \% \\
(20 / 105) \\
\end{array}$ & $5.2 \%(4 / 77)$ & $\begin{array}{c}37.5 \% \\
(45 / 120)\end{array}$ & $\begin{array}{c}6.5 \% \\
(4 / 62) \\
\end{array}$ & $8.5 \%(7 / 82)$ & $\begin{array}{c}15.1 \% \\
(92 / 609) \\
\end{array}$ \\
\hline Patina & 0 & 0 & 0 & $1.3 \%(1 / 77)$ & 0 & 0 & 0 & $\begin{array}{c}0.2 \% \\
(1 / 609)\end{array}$ \\
\hline
\end{tabular}

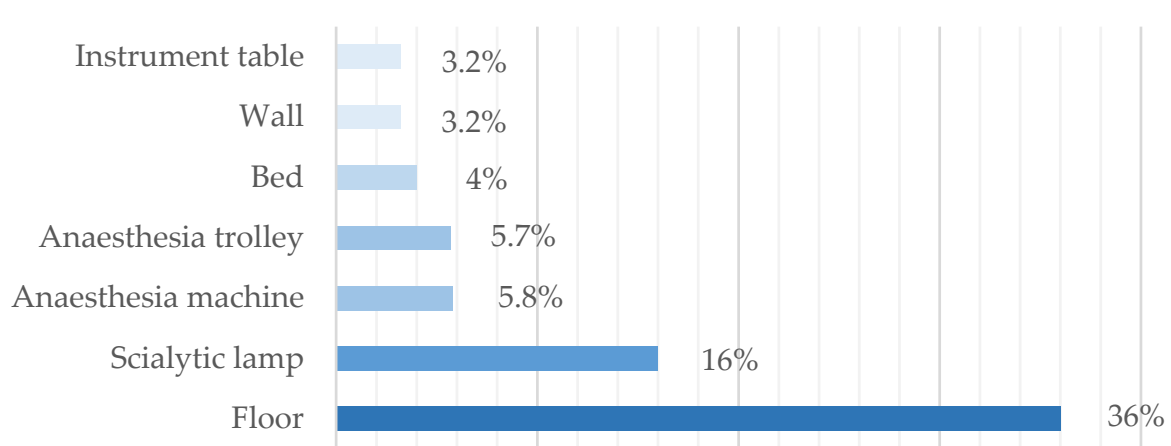

Figure 4. Surfaces: percentage of non-compliant samples.

From a qualitative point of view, critical microorganisms (Staphylococcus aureus, Pseudomonas spp., Enterobacteria and Aspergillus spp.) were present on $16.9 \%$ of contaminated surfaces; in particular, Staphylococcus aureus was present on $2.6 \%(18.8 \%$ of which were MRSA), Pseudomonas spp. on $8 \%$, Enterobacteria on $4.9 \%$ and Aspergillus spp. on $2.6 \%$. Of the non-critical flora isolated, the presence of coagulase-negative methicillin-resistant staphylococci (5.4\%), yeasts (3.1\%), and moulds other than Aspergillus spp. (19.2\%) should be noted. Based on the quantitative and qualitative criteria indicated in the ISPESL Guidelines [16], overall $18.7 \%$ of the samples showed a condition of non-compliance: for solely the quantitative aspect in $6.9 \%$, for solely the qualitative aspect in $8.1 \%$, for both in the remaining $3.7 \%$.

Taking the data for each year separately, the highest percentage of non-compliant samples was recorded in 2012 (36.8\%), against a small number of samplings carried out, and in $2015(28.6 \%)$ (Table 4$)$. 
Table 4. Distribution of non-compliant samples $(\mathrm{K}+)$ of the total number of samplings carried out $(\mathrm{K})$ per room and per year.

\begin{tabular}{|c|c|c|c|c|c|c|c|c|c|c|}
\hline \multirow{2}{*}{ Room } & 2011 & 2012 & 2013 & 2014 & 2015 & 2016 & 2017 & 2018 & 2019 & \multirow{2}{*}{ Total } \\
\hline & $\mathrm{K}+/ \mathbf{K}$ & $\mathbf{K}+/ \mathbf{K}$ & $\mathbf{K}+/ \mathbf{K}$ & $\mathbf{K}+/ \mathbf{K}$ & $\mathbf{K}+/ \mathbf{K}$ & $\mathbf{K}+/ \mathbf{K}$ & $\mathrm{K}+/ \mathbf{K}$ & $\mathrm{K}+/ \mathbf{K}$ & $\mathbf{K}+/ \mathbf{K}$ & \\
\hline 1 & $0 / 6$ & - & $2 / 8$ & $0 / 7$ & $2 / 7$ & $1 / 7$ & $1 / 7$ & $0 / 7$ & $0 / 7$ & $\begin{array}{c}6 / 56 \\
(10.7 \%)\end{array}$ \\
\hline 2 & $1 / 6$ & - & $4 / 7$ & $1 / 7$ & $2 / 7$ & $1 / 7$ & $0 / 7$ & $1 / 7$ & $0 / 7$ & $\begin{array}{c}10 / 55 \\
(18.2 \%)\end{array}$ \\
\hline 3 & - & - & $1 / 7$ & $3 / 7$ & $0 / 7$ & $0 / 7$ & $1 / 7$ & $2 / 7$ & $0 / 7$ & $\begin{array}{c}7 / 49 \\
(14.3 \%)\end{array}$ \\
\hline 4 & - & - & $1 / 7$ & $0 / 7$ & $0 / 7$ & $0 / 7$ & $1 / 7$ & $1 / 7$ & $0 / 7$ & $\begin{array}{c}3 / 49 \\
(6.1 \%)\end{array}$ \\
\hline 5 & $1 / 6$ & - & $2 / 7$ & $1 / 7$ & $3 / 14$ & $2 / 7$ & $0 / 7$ & $1 / 7$ & $1 / 7$ & $\begin{array}{c}11 / 62 \\
(17.7 \%)\end{array}$ \\
\hline 6 & $0 / 6$ & - & $1 / 7$ & $1 / 7$ & $1 / 7$ & $0 / 7$ & $1 / 7$ & $1 / 7$ & $2 / 7$ & $\begin{array}{c}7 / 55 \\
(12.7 \%)\end{array}$ \\
\hline 7 & $1 / 6$ & - & $2 / 7$ & $1 / 7$ & $3 / 7$ & $2 / 7$ & $0 / 7$ & $0 / 7$ & $2 / 7$ & $\begin{array}{c}11 / 55 \\
(20.0 \%)\end{array}$ \\
\hline 8 & $2 / 6$ & - & $3 / 7$ & $1 / 7$ & $1 / 7$ & $2 / 7$ & $0 / 7$ & $1 / 7$ & $1 / 7$ & $\begin{array}{c}11 / 55 \\
(20.0 \%)\end{array}$ \\
\hline 9 & $2 / 6$ & $3 / 6$ & $2 / 15$ & $3 / 7$ & $4 / 7$ & $1 / 14$ & $3 / 7$ & $2 / 7$ & $1 / 7$ & $\begin{array}{c}21 / 76 \\
(27.6 \%)\end{array}$ \\
\hline 10 & $3 / 6$ & $2 / 7$ & $2 / 15$ & $3 / 7$ & $3 / 7$ & $1 / 14$ & $1 / 7$ & $0 / 7$ & $1 / 7$ & $\begin{array}{c}16 / 77 \\
(21.1 \%)\end{array}$ \\
\hline 11 & - & $2 / 6$ & $1 / 15$ & $4 / 7$ & $3 / 7$ & $1 / 14$ & $2 / 7$ & $1 / 7$ & $0 / 7$ & $\begin{array}{c}14 / 70 \\
(20.0 \%)\end{array}$ \\
\hline 12 & - & - & $3 / 7$ & $4 / 7$ & $1 / 7$ & $1 / 7$ & - & - & - & $\begin{array}{c}9 / 28 \\
(32.1 \%)\end{array}$ \\
\hline 13 & - & - & $2 / 7$ & $1 / 7$ & $4 / 7$ & $0 / 7$ & - & $1 / 7$ & - & $\begin{array}{c}8 / 35 \\
(22.9 \%)\end{array}$ \\
\hline 14 & - & - & $2 / 7$ & $1 / 7$ & $3 / 7$ & $2 / 7$ & - & - & - & $\begin{array}{c}8 / 28 \\
(28.6 \%)\end{array}$ \\
\hline 15 & - & - & $1 / 7$ & $4 / 7$ & $2 / 7$ & $1 / 8$ & - & - & - & $\begin{array}{c}8 / 29 \\
(27.6 \%)\end{array}$ \\
\hline 16 & - & - & $1 / 7$ & $0 / 7$ & $2 / 7$ & $1 / 7$ & $1 / 7$ & $0 / 7$ & $0 / 7$ & $\begin{array}{c}5 / 49 \\
(10.2 \%)\end{array}$ \\
\hline 17 & - & - & $1 / 7$ & $2 / 7$ & $2 / 7$ & $2 / 7$ & $1 / 7$ & $0 / 7$ & - & $\begin{array}{c}8 / 42 \\
(19.0 \%)\end{array}$ \\
\hline Total & $\begin{array}{c}10 / 48 \\
(20.8 \%)\end{array}$ & $\begin{array}{c}7 / 19 \\
(36.8 \%)\end{array}$ & $\begin{array}{l}31 / 144 \\
(21.5 \%)\end{array}$ & $\begin{array}{l}30 / 119 \\
(25.2 \%)\end{array}$ & $\begin{array}{l}36 / 126 \\
(28.6 \%)\end{array}$ & $\begin{array}{l}18 / 141 \\
(12.8 \%)\end{array}$ & $\begin{array}{c}12 / 91 \\
(13.2 \%)\end{array}$ & $\begin{array}{c}11 / 98 \\
(11.2 \%)\end{array}$ & $\begin{array}{c}8 / 84 \\
(9.5 \%)\end{array}$ & $\begin{array}{c}163 / 870 \\
(18.7 \%)\end{array}$ \\
\hline
\end{tabular}

\section{Discussion}

Although more than $70 \%$ of the examinations of the air showed bacterial load values which did not conform to the standards indicated for at least one sampling zone, significant contamination both as an entity of the microbial load observed per sampling point and, above all, as a global criticality (all sampling points non-compliant) can be detected in a very small number of examinations and affects a limited number of rooms. Moreover, disaggregating the results by sampling zone, given the different objectives of the evaluation in the at rest room vs. the operational room, it can be observed that over $40 \%$ of the evaluations both in the empty room (44.6\%) and during the surgical procedure $(41.2 \%)$ show values within the compliance range. 
Considering the main variables that under the two different conditions can affect the microbial contamination of the air, it appears possible that the high microbial load values observed may have been determined, especially during surgical activities, mostly by a non-optimal operation and/or maintenance of the air conditioning system. In many cases, in fact, high microbial loads are observed at the level of the air inlet vents, sometimes even higher than those detected at the same time near the bed. However, a certain criticality must also be pointed out in the bed zone when at rest, which may be due to non-optimal sanitisation procedures. It should be noted, however, that the percentage of non-compliant examinations has decreased considerably over the years, with the lowest values shown in recent years. This observation suggests that various management/structural/engineering and behavioural aspects that may influence air quality have been the subject of attention and improved following the sub-standard examination results in the testing carried out.

In terms of quality, bacteria isolated from air samples include Pseudomonadaceae, Enterobacteriaceae, Staphylococcus aureus, and coagulase-negative staphylococci, considered among the main aetiological agents of surgical site infections [6,11,21,22]. Machinery malfunctions may have affected the detection of gram-negative bacteria in the air. Their survival may be enhanced by altered conditions such as high humidity and low temperature [23,24]. Moreover, Pseudomonadaceae, which have also been detected by other authors in the air and on the surfaces of ORs, have a high capacity to survive and spread in hospital environments given their modest nutritional requirements and resistance to commonly used antibiotics and disinfectants [8,25-27]. As far as S. aureus is concerned, its presence in the OR environment could be related to the presence of colonised subjects [28]. In fact, Staphylococcus aureus eliminated in the environment by carrier subjects (patient, operators) can remain vital for long periods of time [29]. The focus on Staphylococcus aureus is such that, since the microorganism may be of endogenous origin, the WHO Global Guidelines for the Prevention of Surgical Site Infections recommend decolonisation in nasal carriers undergoing surgery [1]. In addition, an increasing number of these infections are caused by MRSA [6,21,22]; in these cases, the mortality rate can exceed 70\% [30]. The presence of both MRSA and methicillin-resistant non-aureus staphylococci confirms that methicillin-resistant staphylococci are currently part of the endemic flora in many hospitals [31,32].

Fungal contamination is also considered a very important environmental indicator (although no official limits are set), as it can be related to high humidity and dustiness, reduced ventilation, and, in general, poor air quality [33]. Their frequent isolation, in over $80 \%$ of examinations, would seem to confirm a possible problem with the ventilation system. The higher levels detected in the years 2011 and 2012 could be attributed, at least in part, to construction works in progress at the time in the areas adjacent to the hospital examined. Additionally, in this case, a malfunctioning of the air conditioning systems could have played a role. The risk of SSI from airborne fungi was rarely reported, and mainly in immunodepressed subjects [34].

With a view to better assessing the microbiological quality of the environment, as well as testing the air, surfaces were also tested. These evaluations have shown an overall good level of sanitation of the surfaces examined. In fact, the percentage of non-compliant surfaces detected was relatively low and, in these cases, the judgment of non-compliance was mainly due to the qualitative aspect. The fact that the floors and scialytic lights were found to be the most critical surfaces may suggest that, on occasion, sanitising procedures were not carried out with the same attention to the various surfaces present in the same environment. One might argue, in fact, that more attention is paid to the easier and more conveniently-reached ones, as shown by the fact that the highest-located surface, the scialytic lights, and lowest-located one, the floor, were the least clean. It can also be assumed that the greater attention paid to the other surfaces may have been determined by the different perceptions of the infectious risk associated with them. 


\section{Conclusions}

In the OR, the main way of preventing SSI is by reducing the microorganisms that can reach the surgical wound. As such, it is fundamental that the environment complies with structural, organisational, and managerial norms and adequate behavioural models. The detection of microbial contamination through environmental monitoring may be the indirect expression of shortcomings or failures in the above-mentioned aspects. In terms of prevention, environmental monitoring certainly constitutes a secondary level intervention, mainly aimed at an "early diagnosis" of environmental unhealthiness, as a forewarning of sentinel events. For this reason, it should be carried out by all surgical facilities on a constant, although obviously not daily, basis. Its value transcends the moment in which it is performed, since through monitoring, indications are given of the hygienic-sanitary quality not only of that moment (the status quo) but also of the quality that that environment will always have under the same operating, management and sanitation conditions. Moreover, data on environmental quality could be a useful educational and training tool both for those responsible for the sanitation procedures, since the results reflect the effectiveness and suitability of the procedures adopted, and for the surgical team in order to increase awareness of the effects of a possible non-adherence to behavioural standards.

Author Contributions: Conceptualization, M.D.M. and P.C.; data curation, M.D.M., M.D. (Marco Dettori), G.M.D., A.A. (Antonella Arghittu) and A.A. (Antonio Azara); formal analysis, M.D.M. and G.M.D.; investigation, M.D.M., G.M.D., S.S. and M.D. (Michela Deriu); methodology, M.D.M., M.D. (Marco Dettori), G.M.D., A.A. (Antonio Azara) and P.C.; software, S.S., M.D. (Michela Deriu) and A.A. (Antonella Arghittu); supervision, M.D.M. and P.C.; validation, M.D.M.; writing-original draft, M.D.M., M.D. (Marco Dettori) and M.D. (Michela Deriu); writing—review and editing, M.D.M., M.D. (Marco Dettori), A.A. (Antonio Azara) and P.C. All authors have read and agreed to the published version of the manuscript.

Funding: The research was supported by "Fondo di Ricerca di Ateneo 2019", University of Sassari.

Acknowledgments: The authors would like to thank Emma Dempsey for the English language revision.

Conflicts of Interest: The authors declare no conflict of interest.

\section{References}

1. World Health Organization. Global Guidelines on the Prevention of Surgical Site Infection. 2016. Available online: https: //www.who.int/gpsc/ssi-guidelines/en/ (accessed on 16 November 2020).

2. Zingg, W.; Demartines, N.; Imhof, A.; Senn, G.; Ruef, C. Rapid colonization with methicillin-resistant Coagulase-Negative staphylococci after surgery. World J. Surg. 2009, 33, 2058-2062. [CrossRef] [PubMed]

3. European Centre for Disease Prevention and Control. Healthcare-Associated Infections: Surgical Site Infections; Annual Epidemiological Report for 2017; ECDC: Stockholm, Sweden, 2019.

4. Marchi, M.; Pan, A.; Gagliotti, C.; Morsillo, F.; Parenti, M.; Resi, D.; Moro, M.L.; The Sorveglianza Nazionale Infezioni in Chirurgia [SNICh) Study Group. The Italian national surgical site infection surveillance programme and its positive impact, 2009 to 2011. Euro Surveill. 2014, 19, 20815. Available online: http:/ / www.eurosurveillance.org/ViewArticle.aspx?ArticleId=20815 (accessed on 16 November 2020). [CrossRef] [PubMed]

5. GlobalSurg Collaborative. Determining the worldwide epidemiology of surgical site infections after gastrointestinal resection surgery: Protocol for a multicentre, international, prospective cohort study (GlobalSurg 2). BMJ Open 2017, 7, e012150. [CrossRef] [PubMed]

6. Owens, C.; Stoessel, K. Surgical site infections: Epidemiology, microbiology and prevention. J. Hosp. Infect. 2008, 70, 3-10. [CrossRef]

7. Leaper, D.J.; van Goor, H.; Reilly, J.; Petrosillo, N.; Geiss, H.K.; Torres, A.J.; Berger, A. Surgical site infection-A European perspective of incidence and economic burden. Int. Wound J. 2004, 1, 247-273. [CrossRef]

8. Atata, R.F.; Ibrahim, Y.K.E.; Olurinola, P.F.; Giwa, A.; Akanbi Ii, A.A.; Sani, A.A. Clinical bacterial isolates from hospital environment as agents of surgical wound nosocomial infections. J. Pharm. Bioresour. 2011, 7, 146-155. [CrossRef]

9. Ishida, T.; Nakano, K.; Nakatani, H.; Gomi, A. Bacteriological evaluation of the cardiac surgery environment accompanying hospital relocation. Surg. Today 2006, 36, 504-507. [CrossRef]

10. Lutz, B.D.; Jin, J.; Rinaldi, M.G.; Wickes, B.L.; Huycke, M.M. Outbreak of invasive Aspergillus infection in xurgical patients, zssociated with a contaminated air-handling system. Clin. Infect. Dis. 2003, 37, 786-793. [CrossRef] 
11. Mangram, A.J.; Horan, T.C.; Pearson, M.L.; Silver, L.C.; Jarvis, W.R. Guideline for prevention of surgical site infection, 1999. Centers for Disease Control and Prevention (CDC) Hospital Infection Control Practices Advisory Committee. Am. J. Infect. Control 1999, 27, 97-132. [CrossRef]

12. Charnley, J.; Eftekhar, M. Postoperative infection in total prosthetic replacement arthroplasty of the hip-joint with special reference to the bacterial content of air in the operating room. Br. J. Surg. 1969, 56, 641-649. [CrossRef]

13. Lidwell, O.M.; Lowbory, E.J.L.; Whyte, W.; Blowers, R.; Stanley, S.J.; Lowe, D. Airborne contamination of wounds in joint replacement operations: The rela-tionship to sepsis rates. J. Hosp. Infect. 1983, 4, 11-31. [CrossRef]

14. Pasqualotto, A.C.; Denning, D.W. Post-operative aspergillosis. Clin. Microbiol. Infect. 2006, 12, 1060-1076. [CrossRef] [PubMed]

15. Pitzurra, M.; Pasquarella, C.; D’alessandro, D.; Savino, A. La Prevenzione dei Rischi in Sala Operatoria; Società Editrice Universo: Roma, Italy, 1999.

16. Istituto Superiore Per la Prevenzione E la Sicurezza del Lavoro (ISPESL)—Dipartimento Igiene del Lavoro. Linee Guida Sugli Standard di Sicurezza e di Igiene del Lavoro nel Reparto Operatorio. Available online: https://www.inail.it/cs/internet/docs/ linee-guida-igiene-reparto-operatorio.pdf?section=attivita (accessed on 16 November 2020).

17. National Health Service-Health Technical Memorandum 2025. Ventilation in Healthcare Premises. Available online: https: //www.mintie.com/assets/img/education/NHS\%20Estates\%20-\%20HVAC.pdf (accessed on 1 December 2020.).

18. Pasquarella, C.; Masia, M.D.; Nnanga, N.; Sansebastiano, G.E.; Savino, A.; Signorelli, C.; Veronesi, L. Confronto tra due metodi di cam-pionamento nel monitoraggio microbiologico in sala operatoria: Campionamento attivo e passive/Microbial air monitoring in operating theatre: Active and passive samplings. Ann. Ig. 2004, 16, 375-386. [PubMed]

19. Centers for Disease Control and Prevention (CDC). Guidelines for Environmental Infection Control in Health-Care FacilitiesRecommendation of CDC and the Healthcare Infection Control Practices Advisory Committee (HICPAC); U.S. Department of Health and Human Services: Atlanta, GA, USA, 2003.

20. Streifel, A.J. Air cultures for fungi. In Clinical Microbiology Procedures Handbook; Gilchrist, M., Ed.; American Society for Microbiology Press: Washington, DC, USA, 1992; pp. 11.8.1-11.8.7.

21. De Werra, C.; Schiavone, D.; Di Micco, R.; Triassi, M. Le infezioni del sito chirurgico in Italia. Infez. Med. 2009, 4, $205-218$.

22. Giacometti, A.; Cirioni, O.; Schimizzi, A.M.; Del Prete, M.S.; Barchiesi, F.; D’Errico, M.M.; Petrelli, E.; Scalise, G. Epidemiology and Microbiology of Surgical Wound Infections. J. Clin. Microbiol. 2000, 38, 918-922. [CrossRef] [PubMed]

23. Marthi, B.; Fieland, V.P.; Walter, M.; Seidler, R.J. Survival of bacteria during aerosolization. Appl. Environ. Microbiol. 1990, 56, 3463-3467. [CrossRef] [PubMed]

24. Tang, J.W. The effect of environmental parameters on the survival of airborne infectious agents. J. R. Soc. Interface 2009, 6, 737-746. [CrossRef]

25. Bonadonna, L.; Briancesco, R.; Coccia, A.M.; Della Libera, S.; Fuselli, S.; Gucci, P.M.B.; Iacovacci, P.; Lacchetti, I.; La Rosa, G.; Meloni, P.; et al. Strategie di Monitoraggio Dell'Inquinamento di Origine Biologica Dell'Aria in Ambienti Indoor; Rapporti Istisan 13/37; Istituto Superiore di Sanità: Roma, Italy, 2013.

26. Davane, M. Pseudomonas aeruginosa from hospital environment. J. Microbiol. Infect. Dis. 2014, 4, 42-43. [CrossRef]

27. Ensayef, S.; Al Shalchi, S.; Sabbar, M. Microbial contamination in the operating theatre: A study in a hospital in Baghdad. East. Mediterr. Health J. 2009, 15, 219-223. [CrossRef]

28. Beggs, C.B. The Airborne Transmission of Infection in Hospital Buildings: Fact or Fiction? Indoor Built Environ. 2003, 12, 9-18. [CrossRef]

29. Sands, K.E.F.; Goldmann, D.A. Epidemiology of staphylococcus and group A streptococci. In Hospital Infections, 4th ed.; Bennett, J.V., Brachman, P.S., Eds.; Lippincott-Raven Publishers: Philadelphia, PA, USA, 1998; Chapter 41.

30. Dohmen, P. Influence of Skin Flora and Preventive Measures on Surgical Site Infection during Cardiac Surgery. Surg. Infect. 2006, 7, s13-s17. [CrossRef] [PubMed]

31. Dossier Infad-Anno 2, n. 17, Febbraio 2007. Available online: https://medtriennalisl.campusnet.unito.it/att/ecceinfad200 _infbatresistenti.0.pdf (accessed on 16 November 2020).

32. Seng, R.; Kitti, T.; Thummeepak, R.; Kongthai, P.; Leungtongkam, U.; Wannalerdsakun, S.; Sitthisak, S. Biofilm formation of methicillin-resistant coagulase negative staphylococci (MR-CoNS) isolated from community and hospital environments. PLoS ONE 2017, 12, e0184172. [CrossRef] [PubMed]

33. Istituto Nazionale per l'Assicurazione Contro gli Infortuni sul Lavoro (INAIL). Il Monitoraggio Microbiologico Negli Ambienti di Lavoro. Campionamento e Analisi. Edizione 2010. Available online: https://www.inail.it/cs/internet/comunicazione/ pubblicazioni/catalogo-generale/il-monitoraggio-microbiologico-negli-ambienti-di-lavoro.html (accessed on 1 November 2020.).

34. Kaya, D.; Agartan, C.A.; Yucel, M. Fungal Agents as a Cause of Surgical Wound Infections: An Overview of Host Factors. Wounds 2007, 19, 218-222. [PubMed] 